\title{
Empirical Evidence of Toll Road Traffic Diversion and Implications for Highway Infrastructure Privatization
}

\author{
Peter F. Swan a \\ Michael H. Belzer b
}

November 1, 2007

a

Pennsylvania State University - Harrisburg

School of Business Administration

777 West Middletown Pike

Middletown PA 17057-4898

Email: pfs4@psu.edu

Phone 717-948-6443

Fax: 717-948-6456

b Wayne State University

College of Liberal Arts and Sciences

2220 Academic / Administrative Building

Detroit, MI 48202

e-mail: michael.h.belzer@wayne.edu

Phone: 734-730-3941 (mobile)

Fax: 734-763-0913

\begin{abstract}
Privatization of toll roads is a new policy in the U.S. Although there has been much discussion on how high tolls might go on roads that have been leased under long-term agreements, little empirical work has been done to suggest how private operators might price road access and what effect these pricing policies might have on traffic, the public, and the highways system. This paper empirically demonstrates that tolls can be expected to rise quite significantly and that substantial diversion of trucks is likely to take place. Some of this traffic is likely to divert (as it did in Ohio) to two-lane roads that are inherently less safe than interstate highways. Additionally, the increased cost of freight transportation resulting from such toll increases is likely to have substantial negative effects on interstate commerce and the economy.

The authors wish to thank Stephen Burks, Kristen Monaco, Gordon Proctor, Mike Simon, and Howard Wood for their help with this paper.
\end{abstract}


Keywords:

Public-private partnerships

Freight

Safety

Tolling 


\section{Introduction}

In a speech on May 23 ${ }^{\text {rd }}, 2006$ at the NASDAQ opening bell, the Honorable Norman Mineta, then Secretary of Transportation gave a speech outlining the U.S. Department of Transportation's (USDOT's) new program to reduce congestion on America's transportation network. The plan (USDOT, 2006) consisted of six points including:

1. "Relieve urban congestion" through variable tolling support of rapid bus transit, support of flex scheduling, and financial support for road construction.

2. “Unleash private sector investment resources” by removing regulatory barriers, encouraging states to remove regulatory barriers, overcoming institutional resistance, encouraging public-private partnerships as allowed by existing legislation.

3. "Promote operational and technological improvements" by encouraging systems to enable dynamic route guidance, emphasizing intelligent transportation systems (ITS), as well as identifying and promoting best practices for incident and intersection management.

4. "Establish a 'Corridors of the Future' competition” to accelerate the development of multi-modal and multi-state corridors.

5. “Target major freight bottlenecks and expanding Federal policy outreach" by transforming the DOT's existing Gateway Team into an Intermodal Hot Spot Team, engaging shippers and carriers in discussions structured on the DOT's National Freight Policy Framework, and establishing a DOT, Department of Homeland Security border congestion team.

6. "Accelerate major aviation capacity improvement projects and providing a future funding framework" by designing and implementing the Next Generation Air Transportation System, improving efficiency at New York's La Guardia Airport, giving priority treatment to capacity enhancing projects, and streamlining environmental reviews for aviation capacity projects. ${ }^{1}$

Congestion pricing has been a favorite instrument in the economist's toolbox for some time, and toll roads have been with us in some form for a very long time. Of these six points, however, the effort to "[U]nleash private sector investment resources" (USDOT, 2006) represents the most significant departure from existing policy. The new policy has raised two major issues, both economic and non-economic, that are being debated in the press, by the public, in state government, and in national government. First, does it make good policy sense to substitute the existing fuel-tax-based system of funding road infrastructure with a system that uses widespread toll mechanisms? The current tax-based system has an efficient collection mechanism that can easily accommodate allowance for fuel efficiency and general extent of infrastructure usage, if the public has the will to pay the tax. A toll-based system would charge motorists based on cost (distance times cost per mile) for the roadway used, and/or on value stemming from roadway congestion. If motorists pay a toll to use all roads, not just interstates, such a system likely will require the installation of substantial public and private hardware to track vehicle use, and arguably will compromise privacy by tracking individual movements while requiring expensive periodic billing of motorists. If the USDOT cannot persuade the public to support tolls on all roads, will a mixed system (fuel tax and widespread tolling) provide the best or worst of both worlds? Second, does it make good policy sense to "monetize" highways by granting very long-term leases to private

${ }^{1}$ All emphasis in the original. 
enterprises, which will operate them for profit? Will this result in efficient economic choices and achieve USDOT policies for safety and accessibility? Will the combination of tolling with privatization enhance or exacerbate the effects of the toll system? Clearly, while public highways can pay for themselves either by tolls or by taxes, a privatized highway system must incorporate tolls instead of fuel taxes.

The current debate has been hampered by the dual policy emphasis on congestion pricing (variable tolls), and on privatization (the long-term lease of existing public-access highways to private profit-making enterprises or creation of new privately funded highways). This dual emphasis commingles the issues of highway funding generation, congestion pricing, and privatization, thus making rational discussion more difficult. The current debate also has been hampered by fact that several policies with regard to highway infrastructure funding have been lumped together under the umbrella of publicprivate partnerships (PPPs). PPPs are defined by the USDOT (2004) as

"contractual agreements formed between public and private sector partners, which allow for more private sector participation than is traditional. Such agreements usually involve a government agency contracting with a private company to renovate, construct, operate, maintain, and/or manage a facility or system.”

PPPs for all of these functions have existed for quite some time, but private management of road infrastructure remains relatively rare within the United States. Nevertheless, the USDOT has launched an active campaign to dramatically increase the private management (as a franchise) of what have been historically public facilities.

To improve the quality of the current debate, this paper analyzes the indirect effects of privatization resulting from the policy of charging tolls on limited access highways. Using empirical data based on actual experience of an existing toll road, we evaluate the extent to which tolls divert traffic from limited access divided highways to parallel routes that more likely are two-to-four lane undivided and open-access highways. This is an important consideration because little agreement exists on what level of tolls a private operator would charge and to what extent traffic might divert to other roads based on toll rates established by a private operator. Such diversion could be both substantial and costly, both in operational terms and safety terms. Operationally, existing two-lane roads could become overburdened, making maintenance more expensive and adding to local congestion, transferring cost to taxpayers. Additionally, non-interstate roads are inherently more dangerous than interstate roads, so diversions from interstate roads would likely result in greater property damage and greater loss of life.

\section{Literature}

Early history of road construction and legislation enabling road construction (toll and non-toll) can be found in several sources (CBO, 1997; Klein \& Majewski, 2006; Mitchell, 2006). The use of tolls for financing and maintaining highways was eschewed by many just prior to and with the creation of the Highway Trust Fund (Mitchell, 2006) because of the substantial administrative cost of collecting tolls, time cost to motorists 
queuing at toll plazas, and the impediment to interstate commerce that widespread tolls would represent (CBO, 1997). However, recent technological advancements have made toll collections cheaper and have made it possible to charge tolls with no reduction in traffic flow (Button, 2006).

While there is a wealth of literature on tolling in general and congestion pricing in particular, there has been less written on pricing for private toll roads. Public roads initially were supported by general funds. Federal fuel taxes were imposed in 1932 and tied to the Highway trust fund in 1956 (Small, Winston, \& Evans, 1989). Following World War II, several states imposed a taxes based on weight carried and distance moved (Small et al., 1989). In 1961 a Congressional study was released showing that heavy trucks were not paying their full share of cost based on the road wear they caused. ${ }^{2}$ In a call to action that was never heeded, Small, Winston, and Evans (1989) crafted a convincing manifesto that suggested without quick and fundamental change in highway financing, the nation would be unable to maintain infrastructure and therefore mobility. They suggested replacing fuel taxes with user charges that are based on the marginal cost of highway use. In this way, highways users could always be charged the full cost of highway use and could provide funds for both maintenance and expansion. The authors also suggested that policy makers adopt congestion pricing both to provide an efficient way of allocating demand and to express the true marginal cost of road use by time of day in addition to weight and distance.

Policy makers ignored efforts to replace fuel taxes with user charges or tolls until recently. Similarly, Federal policy makers have ignored calls for increasing the Federal fuel tax. As a result, average user fees in constant 2001 dollars per mile have fallen from a peak of just under six cents 1966 to under three cents in 2005 (TRB, 2006). While highway funding every year becomes less able to maintain the existing system, vehicle miles traveled (VMTs) are growing and leading to increased congestion year by year. Congestion costs exceeded $\$ 63$ billion in 2003, which was more than five times the cost of congestion in 1982 in 2003 dollars (Shrank \& Lomax, 2005). The combination of inadequate maintenance, lack of capital for new capacity, and ever-growing demand has led to renewed calls for tolls. The question of how high rates should rise has been the subject of some debate. Earlier work such as that by Small, Winston, and Evans (1989) suggested that user charges should be based largely on marginal costs. However, marginal costs (and efficient tolls) rise dramatically when demand exceeds capacity. Pricing to maintain free flow conditions on California's SR-91 resulted in lower approval of both variable tolling and private toll operations (Sullivan, 2003). The Province of Ontario, Canada, leased ETR 407 in Toronto to 407 International, Inc., which is owned by three investment groups (subsidiaries of Cintra, Macquarie, and SNC-Lavalin) to improve traffic flow. While the operator of ETR 407 has met all traffic thresholds, it has done so by raising toll rates during rush hour, which has led to government attempts to force toll rate reductions (Canada Newswire, 2005a, 2005b).

While the determination of how high toll rates should go to provide free-flowing traffic on otherwise congested highways can be calculated objectively, the same cannot

\footnotetext{
${ }^{2}$ Small, Winston, and Evans (1989) cited U.S. Bureau of Public Roads, Final Report of the Highway Cost Allocation Study, 87 Cong. 1 sess., House Doc. 54 (GPO, 1961)
} 
be said for rural roads that are not congested. For situations where traffic is free-flowing, the questions of user charge levels or rate-setting mechanisms are harder to answer. Ideally, user charges would be determined by marginal cost, but interstate roads often represent quasi-monopolies. While roads rarely are true monopolies, the substitutes for any particular road often can be greatly inferior in time, distance, and cost of use. For roads without good substitutes, the low elasticity of demand would allow a private operator to follow a monopoly-pricing strategy and set prices at the level where marginal long-run ${ }^{3}$ revenue equals long-run marginal cost (Pindyck \& Rubinfeld, 1998). In other situations where multiple perfect substitutes exist, rates (as well as supply and demand) would be set competitively where marginal cost, marginal revenue, and price would all be equal. Given that each road is different, private road operators likely would face a competitive situation closer to monopoly than to perfect competition. Theory suggests that a private road operator would collect rents limited only by the availability and adequacy of substitute roads.

In these situations, privatization of public interstates necessarily will lead to prices that exceed marginal cost (of infrastructure), even in situations where congestion is not a problem. Recent lease agreements limit annual toll increases but allow tolls to rise faster than inflation (measured by the consumer price index [CPI]) when inflation is below two percent or when nominal increase in nominal gross domestic product per capita (GDP) is above inflation (maximum allowed annual increase is the maximum of the three measures: Enright, 2006). Given that annual GDP increases averaged over seven percent over the last fifty years, truck tolls for the Indiana Turnpike could rise 3,876\% over the 75 year lease of the Toll Road (based on 4\% annual increase in GDP per capita: Enright, 2006). Poole (2005) and Schmidt (2005) both point out that the existence of substitutes effectively will limit toll increases. However, the limits to toll rates that other non-tolled roads provide to private roads may be limited where the limited capacity of the "free" road results in lower elasticity of demand for the private road (Gronau, 1999).

In either case, toll rates significantly above marginal cost might be bad for the economy. Allen (2005) wrote that intrastate motor carriage regulations cost the U.S. economy approximately $\$ 2.5$ billion per year in lost wealth prior to intrastate deregulation in $1995 .{ }^{4}$ The losses come from shippers that pay a higher price made necessary by the absence of competition and from the lower than optimal use of intrastate trucking resulting from that higher price. Thus, toll rates above marginal cost would result in higher prices for all goods. This would include both goods transported via toll roads and goods diverted to less efficient means of transportation.

${ }^{3}$ Demand has both short-run and long-run elasticity. In the short-run, users can divert to other highways or to intermodal. In the long-run, plants can be moved, distribution centers can be moved, and ocean shipping lanes can be changed. Operators of a toll road should base rates on long-term elasticity of demand in order to maximize profits in the long-run (Lee, 2002).

${ }^{4}$ The Federal Aviation Administration Act of 1994 deregulated intrastate truck rates on a national basis (Allen 2005). Becasue the Motor Carrier Act of 1980 only eliminated economic regulation for interstate trucking, this Act made national trucking deregulation complete, extending this policy to shipments that both originated and terminated in the same state. 


\section{Data}

While recently privatized roads do not have enough history under privatization to determine how high rates actually would rise, adequate data exist to determine what happens when toll rates increase dramatically on state-run toll roads. The Ohio Turnpike substantially increased tolls during the $1990 \mathrm{~s}^{5}$ to help finance construction of a third lane in each direction over substantial portions of the Turnpike. Data exist on Ohio truck vehicle miles traveled (VMTs), U.S. truck VMTs, and Ohio Turnpike VMTs (19732005). Because the Ohio Turnpike raised its rates for trucks during the 1990s and later lowered them again, sufficient data exist to calculate a demand curve for the Ohio Turnpike based on demand and the toll rate. We then use the resulting demand curve to estimate diversion of trucks caused by the changes in the toll rates and to forecast how toll rates might affect Turnpike truck revenue. Additionally, we can compare data on daily Ohio truck traffic by road segment with estimated diversions to measure the extent of truck road usage by trucks diverted from the Ohio Turnpike.

The data come from three major sources. U.S. annual VMTs were obtained from the Federal Highway Administration's website (FHWA, 1974-2007). Ohio Turnpike VMTs were obtained from the Turnpike's annual reports (Ohio Turnpike Commission, 1983, 1992, 2006). We obtained Ohio annual VMTs and annual daily vehicle counts for specific road sections and for the state as a whole from the Ohio Department of Transportation.

\section{Methodology}

We measure turnpike truck demand as a single variable because the data available do not differentiate VMTs by truck type; however, the rates for various types of trucks are very strongly correlated. Aside from truck tolls, Ohio Turnpike demand is affected by overall demand for truck transportation and the speed limit used by the Turnpike. ${ }^{6}$ We use total annual U.S. truck VMTs (US Truck VMTs) to represent changes in annual VMTs that could use the Turnpike. ${ }^{7}$ This variable serves as a control for all outside forces affecting Turnpike use. Although several decades of data on U.S. truck VMTs

${ }^{5}$ Tolls for fully loaded five-axle trucks (Turnpike Class 8) were $\$ 21.50$ to travel the entire Turnpike before 1983. In 1983, the Turnpike raised the rate to $\$ 23.25$, where it stood until 1994. Between 1995 and 2001, the rate rose gradually to settle eventually at $\$ 42.45$ in 2001 (a nominal 82.6\% increase in just six years). The Turnpike used the increase to finance an on-going capacity-expansion program. In 2005 the rate declined to \$31 because of a subsidy provided by the State of Ohio.

${ }^{6}$ The speed limit on the Ohio Turnpike was raised from 55 miles per hour to 65 miles per hour in early September 2004 in an effort to attract more trucks to the toll road.

${ }^{7}$ Several variables were considered to represent overall demand. We ruled out Total Ohio truck VMTs because diversions from the Turnpike would increase Ohio VMTs, thus making it an endogenous variable. Also, much of the Ohio Turnpike's traffic is interstate traffic rather than intrastate traffic. We considered an instrument using VMTs for Michigan, Indiana, and Pennsylvania, but ruled it out because total U.S. truck VMTs had a better fit to the data and we perceived it to be less susceptible to errors in measurement at the state level (assuming such errors are random). 
exist, only data after 1989 are used based on the assumption that the relationship between recent U.S. truck VMTs and Turnpike traffic may have changed systematically over time. The speed limit for the Turnpike increased during the study term from fifty-five miles per hour to sixty-five miles per hour. The change took place early in September in 2004. The average annual truck speed limit (Speed) represents this change. ${ }^{8}$ We used tolls for class eight trucks to represent toll rates. The Turnpike Authority increased tolls by about 60 percent between 1995 and 1999 and reduced them again in February of 2005 (Ohio, 2004). Toll rates are the cost of traveling the entire turnpike for a five-axle truck (Nominal Rate), and by the same number adjusted to reflect changes in the U.S. producer price index in 1982 dollars (Real_Rate: BLS, 2007).

Estimating the diversion from the Ohio Turnpike based on toll rates incorporates several assumptions, including the model form, the independent variables, and the dependent variable. We use Turnpike truck VMTs as the dependent variable because the purpose of the model is to measure traffic. The determination of profit-maximizing toll rates requires that toll road operators set rates to the point at which elasticity of demand equals one (Gronau, 1999). This assumption of non-constant elasticity requires the use of a linear demand model rather than a log-linear model (Pindyck \& Rubinfeld, 1998). We estimate the model without constants because in a world with zero U.S. truck VMTs, there would be zero Turnpike VMTs. Additionally, because the effects of Speed, Nominal Rate, and Real Rate are multiplied by the amount of traffic that is available to travel on the Turnpike, we must model the product of each in conjunction with US Truck VMTs. Finally, we model Nominal Rate and Real Rate separately because they are highly correlated. Formulation 1 provides this estimation. Alternatively, we can calculate a simpler version of the model by dividing both sides of Formulation 1 by US Truck VMTs, resulting in Formulation 2. We use Formulation 2 because it is simpler to estimate and easier to understand.

Formulation 1:

Turnpike_Truck_VMTs $i=\beta_{1}{ }^{*}$ US_Truck_VMTs ${ }_{i}{ }^{+} \beta_{2}{ }^{*}$ US_Truck_VMTs $_{i}{ }^{*}$ Real Ratei ${ }^{+}{ }_{3}{ }^{*}{ }^{*}$ US_Truck_VMTs $_{i}{ }^{*} \operatorname{Speed}_{i}{ }^{+} \varepsilon i$ Formulation 2:

Turnpike_Truck_VMTṣ $/$ US_Truck_MMTs ${ }_{i}=\alpha+{ }_{1}{ }^{*}{ }$ RealRatei $^{+}{ }_{2}{ }^{*}$ Speed $_{i}{ }^{+} \varepsilon i$

\footnotetext{
${ }^{8}$ Because 2004 had the increased speed limit for almost one third of the year, we assume an average speed limit of fifty-eight miles per hour, while the speed limit in 2005 was sixty-five miles per hour for trucks.
} 
Table 1

Turnpike Data

\begin{tabular}{|c|c|c|c|c|c|}
\hline Variable & Obs & Mean & $\begin{array}{c}\text { Std. } \\
\text { Dev. }\end{array}$ & Min & Max \\
\hline US_Truck VMTs (billions) & 16 & 188.85 & 26.56 & 146.24 & 222.84 \\
\hline Turnpike VMTs (millions) & 16 & 788.53 & 93.27 & 642.21 & 1026.54 \\
\hline $\begin{array}{c}\text { Turnpike VMTs / US } \\
\text { Truck VMTs }\end{array}$ & 16 & 4.20 & 0.302 & 3.74 & 4.68 \\
\hline Nominal_Rate (entire road) & 16 & $\$ 33.20$ & $\$ 8.65$ & $\$ 23.25$ & $\$ 42.45$ \\
\hline Real_Rate (1982 dollars & 16 & $\$ 23.60$ & $\$ 5.30$ & $\$ 16.95$ & $\$ 29.94$ \\
\hline Speed & 16 & 55.81 & 2.56 & 55 & 65 \\
\hline
\end{tabular}

Table 2

Turnpike Traffic Pairwise Correlations $(\mathrm{n}=16)$

\begin{tabular}{|c|c|c|c|c|}
\hline & $\begin{array}{c}\text { Turnpike } \\
\text { VMTs / } \\
\text { US Truck } \\
\text { VMTS }\end{array}$ & $\begin{array}{c}\text { Nominal_ } \\
\text { Rate }\end{array}$ & $\begin{array}{c}\text { Real } \\
\text { Rate }\end{array}$ & Speed \\
\hline $\begin{array}{c}\text { Turnpike VMTs / US } \\
\text { Truck VMTS }\end{array}$ & 1 & & & \\
\hline Nominal_Rate & $-0.826 * * *$ & 1 & & \\
\hline Real_Rate & $-0.837 * * *$ & $0.990 * * *$ & 1 & \\
\hline Speed & 0.307 & 0.017 & -0.078 & 1 \\
\hline$* * * \mathrm{p}<.001$ & $* * \mathrm{p}<.01$ & $* \mathrm{p}<.05$ & & \\
\hline
\end{tabular}

\section{Results: Estimating Truck Diversion}

Descriptive statistics for the data used are shown in Table 1 and pair-wise correlations are shown in Table 2. Table 3 shows the results of the OLS regression models. ${ }^{9}$ Of the two, Model 1, using nominal rates, has the best fit but is very close to Model 2, which uses real rates. Both models show the expected results. The analysis links higher toll rates to reductions in the ratio of Turnpike truck VMTs to US truck VMTs, and thus to lower Turnpike truck VMTs. Analysis also links higher speed limits to increases in the ratio of Turnpike truck VMTs to US truck VMTs, and thus to increases in Turnpike traffic.

${ }^{9}$ Based on a Durbin's alternative test, we cannot reject the null hypothesis that error terms are not autocorrelated. 
Table 3

OLS Results

\begin{tabular}{|c|c|c|}
\hline $\begin{array}{c}\text { Independent } \\
\text { Variables }\end{array}$ & $\begin{array}{c}\text { Model 1 } \\
\text { Coefficients }\end{array}$ & $\begin{array}{c}\text { Model 2 } \\
\text { Coefficients }\end{array}$ \\
\hline Constant & $3.05^{* *}$ & $3.70^{* *}$ \\
\hline Nominal Rate & $-0.0291^{* * *}$ & \\
\hline Real Rate & & $-0.0467 * * *$ \\
\hline Speed & $0.0379^{*}$ & 0.0287 \\
\hline $\mathrm{F}(2,13)$ & $23.72^{* * *}$ & $20.48^{* * *}$ \\
\hline $\mathrm{N}$ & 16 & 16 \\
\hline $\begin{array}{c}\text { Adjusted R- } \\
\text { squared }\end{array}$ & 0.7518 & 0.7220 \\
\hline$* * * \mathrm{p}<.001$ & ${ }^{* *} \mathrm{p}<.01$ & $* \mathrm{p}<.05$ \\
\hline
\end{tabular}

We use Model 2 to estimate diversions from the Turnpike, assuming that controlling for inflation is important, but either model produces similar diversions. ${ }^{10}$ Using this model, one can estimate the amount of truck traffic diversion from the Ohio Turnpike to other Ohio roads. Table 4 shows actual Turnpike VMTs 1990 through 2005, predicted VMTs using actual rates, predicted VMTs based on no rate increases after 1994, and estimated diverted VMTs.

${ }^{10}$ Two effects appear to be at work here. The psychological effect of increases in nominal rates and the effect of the rate in real dollars on total logistics cost. We assume that effects of nominal rates will be shorter term and therefore use the model containing real dollars. 
Table 4

Ohio Turnpike VMTs (millions)

\begin{tabular}{|c|c|c|c|c|c|c|}
\hline \multirow{2}{*}{$\begin{array}{l}\text { Year } \\
1990\end{array}$} & \multirow{2}{*}{$\frac{\text { Actual }}{684}$} & \multirow{2}{*}{$\begin{array}{c}\text { Predicted } \\
641\end{array}$} & \multirow{2}{*}{$\begin{array}{c}\text { Predicted } \\
\text { Steady } \\
\text { Toll Rate }\end{array}$} & \multirow{2}{*}{$\begin{array}{c}\begin{array}{c}\text { Estimated } \\
\text { Diverted } \\
\text { VMTs }\end{array} \\
0\end{array}$} & \multicolumn{2}{|c|}{$\begin{array}{c}95 \text { Percent } \\
\text { Confidence Interval } \\
\text { for Diverted VMTs }\end{array}$} \\
\hline & & & & & 0 & 0 \\
\hline 1991 & 642 & 661 & 661 & 0 & 0 & 0 \\
\hline 1992 & 668 & 682 & 682 & 0 & 0 & 0 \\
\hline 1993 & 704 & 714 & 714 & 0 & 0 & 0 \\
\hline 1994 & 777 & 764 & 764 & 0 & 0 & 0 \\
\hline 1995 & 798 & 788 & 802 & 14 & 9 & 19 \\
\hline 1996 & 782 & 788 & 826 & 37 & 24 & 51 \\
\hline 1997 & 752 & 787 & 864 & 76 & 49 & 104 \\
\hline 1998 & 772 & 784 & 886 & 102 & 65 & 138 \\
\hline 1999 & 837 & 787 & 915 & 128 & 82 & 174 \\
\hline 2000 & 851 & 801 & 930 & 128 & 82 & 174 \\
\hline 2001 & 804 & 818 & 947 & 129 & 83 & 176 \\
\hline 2002 & 815 & 839 & 972 & 133 & 85 & 181 \\
\hline 2003 & 814 & 854 & 988 & 134 & 86 & 182 \\
\hline 2004 & 890 & 890 & 1023 & 133 & 85 & 181 \\
\hline 2005 & 1,027 & 1,025 & 1,078 & 54 & 34 & 73 \\
\hline
\end{tabular}

We can estimate the revenue and marginal revenue ${ }^{11}$ for a private operator based on this same information from the demand model for the Turnpike. Table 5 is based on Model 2 and shows total VMTs, total revenue, and marginal revenue at various toll rates in dollars per VMT based on 2004 traffic data. While numbers shown in Table 5 (and used in Figures 1 and 2) are only projections based on observed data, the principle on which a private operator might set price would be unchanged, even if the magnitude of the specific numbers is over- or under-estimated. Reebie Associates (Bryan et al., 2004) demonstrated a similar effect when they estimated that the rate of truck diversion for I-81 during 2003 would be highest for toll rates between sixteen and thirty cents per mile, but that diversions continued to increase with higher tolls. Additionally, using data from Proctor and Merckel (2004), we assume long-run marginal cost per truck VMT to be $\$ 0.12 .^{12}$

${ }^{11}$ Admittedly, the marginal revenue measured here is short-term. However, given the speed that freight carriers react to changes in toll rates and given that the elasticity of freight demand is dependent on demand for products and not the price of freight (Fair \& Williams, 1975), the difference between short-run and long-run should not be too great.

12 Toll rates in dollars per VMT for loaded five-axle trucks on four representative toll roads (Pennsylvania is excluded because it is an obvious outlier) from Proctor and Merckel (2004) yields an average toll rate of twelve cents per VMT. Although actual marginal cost probably is lower than this number, it is a good approximation. 
Table 5

Estimated Turnpike VMTs, Total Revenue, and Marginal Revenue versus Toll Rate

\begin{tabular}{|c|c|c|c|c|}
\hline $\begin{array}{l}\text { Nominal Rate in } \\
\text { Dollars per Mile }\end{array}$ & $\begin{array}{c}\text { Rate in } 1982 \\
\text { Dollars per } \\
\text { Mile }\end{array}$ & $\begin{array}{l}\text { Truck VMTs } \\
\text { (millions) }\end{array}$ & $\begin{array}{c}\text { Gross Truck Toll } \\
\text { Revenue }\end{array}$ & $\begin{array}{l}\text { Marginal Revenue } \\
\text { per VMT }\end{array}$ \\
\hline$\$ 0.00$ & $\$ 0.00$ & 1,240 & $\$ 0$ & \\
\hline$\$ 0.01$ & $\$ 0.01$ & 1,223 & $\$ 8,231,768$ & $-\$ 0.49$ \\
\hline$\$ 0.02$ & $\$ 0.01$ & 1,206 & $\$ 16,236,465$ & $-\$ 0.47$ \\
\hline$\$ 0.03$ & $\$ 0.02$ & 1,189 & $\$ 24,014,092$ & $-\$ 0.46$ \\
\hline$\$ 0.04$ & $\$ 0.03$ & 1,173 & $\$ 31,564,650$ & $-\$ 0.45$ \\
\hline$\$ 0.05$ & $\$ 0.03$ & 1,156 & $\$ 38,888,137$ & $-\$ 0.43$ \\
\hline$\$ 0.10$ & $\$ 0.07$ & 1,071 & $\$ 72,099,519$ & $-\$ 0.37$ \\
\hline$\$ 0.15$ & $\$ 0.10$ & 987 & $\$ 99,634,148$ & $-\$ 0.30$ \\
\hline$\$ 0.20$ & $\$ 0.13$ & 903 & $\$ 121,492,024$ & $-\$ 0.23$ \\
\hline$\$ 0.25$ & $\$ 0.17$ & 818 & $\$ 137,673,146$ & $-\$ 0.16$ \\
\hline$\$ 0.30$ & $\$ 0.20$ & 734 & $\$ 148,177,514$ & $-\$ 0.10$ \\
\hline$\$ 0.35$ & $\$ 0.24$ & 650 & $\$ 153,005,128$ & $-\$ 0.03$ \\
\hline$\$ 0.36$ & $\$ 0.24$ & 633 & $\$ 153,289,440$ & $-\$ 0.02$ \\
\hline$\$ 0.37$ & $\$ 0.25$ & 616 & $\$ 153,346,683$ & $\$ 0.00$ \\
\hline$\$ 0.38$ & $\$ 0.26$ & 599 & $\$ 153,176,855$ & $\$ 0.01$ \\
\hline$\$ 0.39$ & $\$ 0.26$ & 582 & $\$ 152,779,957$ & $\$ 0.02$ \\
\hline$\$ 0.40$ & $\$ 0.27$ & 565 & $\$ 152,155,989$ & $\$ 0.04$ \\
\hline$\$ 0.45$ & $\$ 0.30$ & 481 & $\$ 145,630,095$ & $\$ 0.10$ \\
\hline$\$ 0.50$ & $\$ 0.34$ & 397 & $\$ 133,427,449$ & $\$ 0.17$ \\
\hline$\$ 0.55$ & $\$ 0.37$ & 314 & $\$ 115,961,268$ & $\$ 0.24$ \\
\hline$\$ 0.60$ & $\$ 0.40$ & 228 & $\$ 91,991,894$ & $\$ 0.31$ \\
\hline$\$ 0.65$ & $\$ 0.44$ & 143 & $\$ 62,758,986$ & $\$ 0.37$ \\
\hline$\$ 0.70$ & $\$ 0.47$ & 59 & $\$ 27,849,325$ & $\$ 0.44$ \\
\hline
\end{tabular}

\section{Discussion: Truck Diversion}

How would a profit-maximizing toll authority set tolls, following these market dynamics? A profit maximizer might set tolls by comparing total revenue to toll rates as shown in Figure 1. In 2004, we estimate that maximum revenue can be achieved at a toll rate of $\$ 0.25$ per VMT in 1982 dollars, or $\$ 0.37$ in nominal dollars. It is worth noting that profitability is maximized at some rate above the rate that maximizes revenue because each VMT generates some marginal cost. Profits would be maximized where the lost revenue from decreased traffic (at a higher VMT rate) would exactly offset the lower maintenance cost for lower traffic. This is the point where marginal revenue equals marginal cost as shown in Figure 2. This occurs at a toll rate of \$0.31 in 1982 dollars or $\$ 0.46$ in nominal dollars. At this rate, fully loaded semi-trucks traversing the entire Turnpike would pay $\$ 111$ in nominal dollars. Such a toll rate would produce an estimated diversion of 608 million truck VMTs in 2004, when compared with the VMTs at the nominal toll rate used in 1994. This level of diversion is more than four times that which initially caused the State of Ohio to subsidize truck traffic on the Ohio Turnpike in 2005. 
Figure 1

Total Revenue versus Toll Rate per VMT

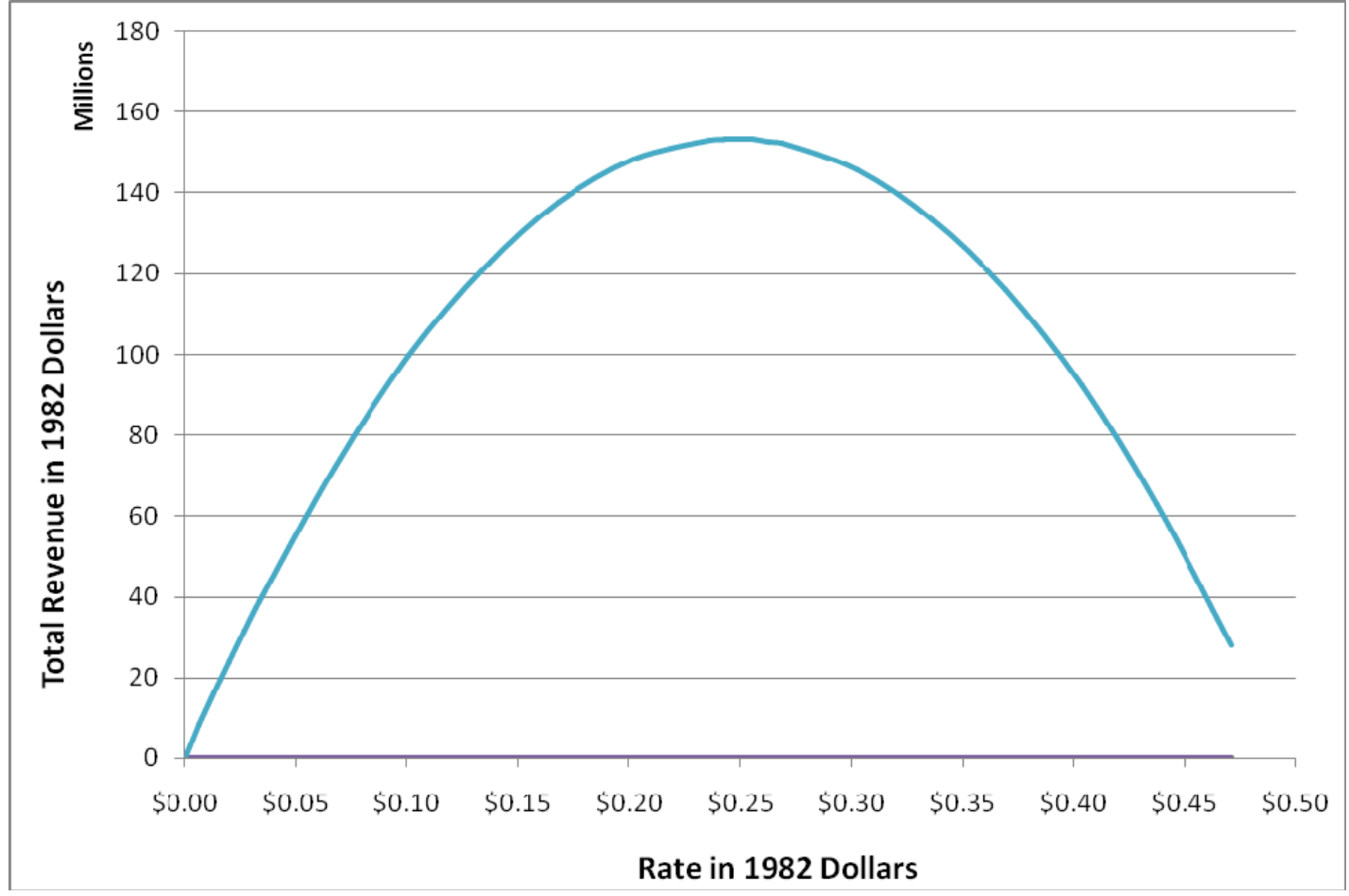


Figure 2

Marginal Revenue and Marginal Cost versus VMTs

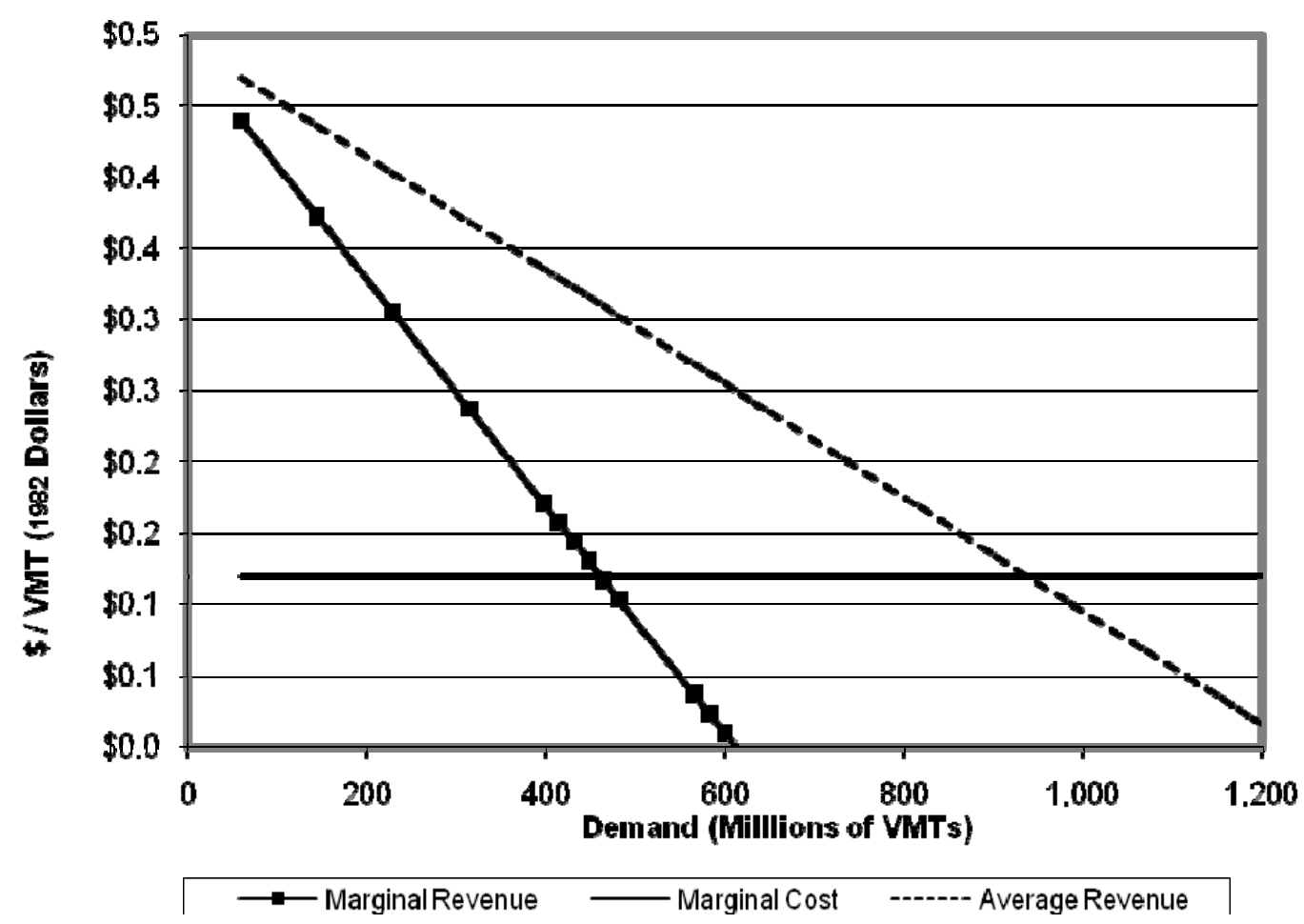

\section{Methodological Extension: Estimating the Effects on Other Ohio Roads}

To further model Ohio Turnpike truck diversion, we compare the estimated diverted VMTs to actual truck traffic counts on selected Ohio roads (Daily Local Trucks). The Ohio Department of Transportation (ODOT) collects average daily traffic counts (cars and trucks counted separately) on a triennial basis. These traffic counts are collected at multiple points on each road, although the year of collection is usually the same for each road in each county. To control for growth, during the period of study, we use daily Ohio truck VMTs (Daily Ohio VMTs). Ohio VMTs are used instead of US VMTs because this traffic is assumed to be primarily intrastate in nature. We also include the estimated diverted VMTs from the previous model as an independent variable (Diverted VMTs). Table 6 shows descriptive statistics for the data and Table 7 shows pairwise correlations for the variables. 
Table 6

Descriptive Statistics for Diversion Effect on Other Roads

\begin{tabular}{|l|c|c|c|c|c|}
\hline Variable & Obs & Mean & Std. Dev. & Min & Max \\
\hline Daily Local Trucks & 3,460 & 5,546 & 5,133 & 30 & 21,770 \\
\hline $\begin{array}{l}\text { Diverted VMTs } \\
\text { (tens of millions) }\end{array}$ & 3,460 & 8.70 & 5.36 & 0 & 13.4 \\
\hline $\begin{array}{l}\text { Daily Ohio VMTS } \\
\text { (millions) }\end{array}$ & 3,460 & 25 & 3 & 19 & 29 \\
\hline
\end{tabular}

Table 7

Pairwise Correlation for Diversion Effect on Other Roads

\begin{tabular}{|c|c|c|c|}
\hline Variable & $\begin{array}{c}\text { Daily Local } \\
\text { Trucks }\end{array}$ & $\begin{array}{c}\text { Diverted } \\
\text { VMTs }\end{array}$ & $\begin{array}{c}\text { Daily Ohio } \\
\text { VMTS }\end{array}$ \\
\hline $\begin{array}{c}\text { Daily Local } \\
\text { Trucks }\end{array}$ & 1 & 1 & \\
\hline $\begin{array}{c}\text { Diverted } \\
\text { VMTs }\end{array}$ & $0.130^{* * *}$ & $0.800^{* * *}$ & 1 \\
\hline $\begin{array}{c}\text { Daily } \\
\text { Ohio_VMTS }\end{array}$ & $0.133^{* * *}$ & & \\
\hline
\end{tabular}

We group these traffic counts by road and by the route that diverted traffic is likely to follow. Table 8 shows the roads/routes studied as possible diversion routes for trucks avoiding the Turnpike. We calculate a simple linear regression model using the panel data for each route. The panel structure controls for local traffic using multiple annual measures for each measuring location. In each case, the average daily number of trucks (Daily Local Trucks) is the dependent variable. The resulting model for road segments 1 through $\mathrm{j}$ and years 1 through $i$ is:

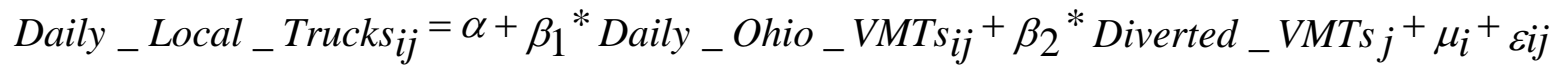

We use a null hypothesis that all coefficients for Diverted VMTs will be zero and an alternative hypothesis that each will greater than zero, indicating that diverted traffic from the Turnpike ended up on each particular road segment. Because Ohio only measures vehicle counts every three years or so on any given road, the panel is unbalanced and uses periodic data. Besides limiting data available for analysis, this also makes it impossible to control for any serial correlation of the data. Additionally, the set of years available may confound the effects measured. 
Table 8

\begin{tabular}{|c|c|c|}
\hline Road & Beginning of Segment & End of Segment \\
\hline $\mathrm{OH} 163$ & $\mathrm{OH} 2$ & $\mathrm{OH} 420$ \\
\hline $\mathrm{OH} 18 \mathrm{E}$ & I 71 & I 77 \\
\hline $\mathrm{OH} 18 \mathrm{~W}$ & US 20 & I 71 \\
\hline $\mathrm{OH} 2 \mathrm{E}$ & I 90 & US 6 \\
\hline $\mathrm{OH} 2 \mathrm{M}$ & US 6 & I 280 \\
\hline $\mathrm{OH} 2 \mathrm{~W}$ & I 475 & US 20 Alt \\
\hline $\mathrm{OH} 8$ & I 76 & I 271 \\
\hline $\mathrm{OH} 82$ & $\mathrm{OH} 5$ & $\mathrm{OH} 11$ \\
\hline US 20 / 20Alt E & $\mathrm{OH} 2$ & $\mathrm{OH} 420$ \\
\hline US 20 / Alt W & US 20 (Williams Co.) & $\mathrm{OH} 64$ \\
\hline US 20 / OH 10 & $\mathrm{OH} 18$ & Turnpike \\
\hline US 20 Alt M & $\mathrm{OH} 108$ & $\mathrm{OH} 2$ \\
\hline US $20 \mathrm{M} 1$ & $\mathrm{OH} 412$ & US 250 \\
\hline US $20 \mathrm{M} 2$ & $\mathrm{OH} 420$ & US 6 \\
\hline US $20 \mathrm{~W} 1$ & US 20 ALT & I 475 \\
\hline US $20 \mathrm{~W} 2$ & $\mathrm{OH} 49$ & US 20 ALT \\
\hline US $20 \mathrm{~W} 3$ & $\mathrm{OH} 49$ & IN \\
\hline US 224 & SR 18 & IN \\
\hline US $224 \mathrm{E}$ & US 250 & I 71 \\
\hline US $224 \mathrm{~W}$ & $\mathrm{OH} 18$ & US 250 \\
\hline US 24 & I 475 & US 6 \\
\hline US $250 \mathrm{~N}$ & US 20 & US 224 \\
\hline US $250 \mathrm{~S}$ & US 224 & US 30 \\
\hline US $30 \mathrm{E}$ & I 71 & PA \\
\hline US $30 \mathrm{M}$ & I 75 (excluding Columbus) & I 71 \\
\hline US $30 \mathrm{~W}$ & IN & I 75 \\
\hline US 33 & Columbus & IN \\
\hline US $422 \mathrm{E}$ & $\mathrm{OH} 44$ & $\mathrm{OH} 82$ \\
\hline US $422 \mathrm{~W}$ & I 271 & $\mathrm{OH} 44$ \\
\hline US $6 \mathrm{E}$ & US 20 & $\mathrm{OH} 2$ \\
\hline US 6 W1 & US 24 & $\mathrm{OH} 53$ \\
\hline US 6 W2 & IN & US 24 \\
\hline I 475 & All & \\
\hline I $70 \mathrm{E}$ & PA & Columbus \\
\hline $\mathrm{I} 70 \mathrm{M}$ & Columbus & I 75 \\
\hline I $70 \mathrm{~W}$ & I 75 & IN \\
\hline $\mathrm{I} 71 \mathrm{M}$ & I 76 & US 30 \\
\hline I $71 \mathrm{~N}$ & I 271 & I 80 \\
\hline I $71 \mathrm{~S}$ & US 30 & Columbus \\
\hline I $75 \mathrm{M}$ & US 30 & I 70 \\
\hline I 75 N1 & Toledo & US 224 \\
\hline I 75 N2 & US 224 & US30 \\
\hline I $76 \mathrm{E}$ & I 80 & Akron \\
\hline I $76 \mathrm{~W}$ & Akron & I 71 \\
\hline I 77 & I 76 & I 271 \\
\hline
\end{tabular}


Table 9

Estimated Diversions versus Actual Daily Truck Traffic

\begin{tabular}{|c|c|c|c|c|c|c|c|}
\hline Road & $\begin{array}{l}\text { Coefficient } \\
\text { for Diverted } \\
\text { VMTS } \\
\text { (trillions) } \\
\end{array}$ & $\begin{array}{l}\text { Coefficient for } \\
\text { Daily Ohio } \\
\text { Truck VMTs } \\
\text { (millions) }\end{array}$ & Constant & F-Statistic & $\begin{array}{c}\mathrm{R} \\
\text { squared } \\
\text { within } \\
\text { groups } \\
\end{array}$ & $\mathrm{N}$ & Groups \\
\hline $\mathrm{OH} 163$ & 57.1 & -63.9 & 1,495 & 3 & .24 & 33 & 11 \\
\hline $\mathrm{OH} 18 \mathrm{E}$ & 109* & -129 & $4,744 * *$ & 9** & .54 & 24 & 6 \\
\hline $\mathrm{OH} 18 \mathrm{~W}$ & 68.5*** & $-92.1 * * *$ & $3,011 * * *$ & $30 * * *$ & .44 & 105 & 28 \\
\hline $\mathrm{OH} 2 \mathrm{E}$ & $275^{* * *}$ & -165 & $6,115 * *$ & $85 * * *$ & .76 & 76 & 21 \\
\hline $\mathrm{OH} 2 \mathrm{M}$ & $125 * *$ & -109 & $4,688 * *$ & $13 * * *$ & .29 & 91 & 27 \\
\hline $\mathrm{OH} 2 \mathrm{~W}$ & 27.6 & -71.4 & 2,998 & 0.6 & .07 & 24 & 6 \\
\hline $\mathrm{OH} 8$ & 37.1 & -89.9 & 6,764 & 0.6 & .02 & 104 & 26 \\
\hline $\mathrm{OH} 82$ & 9.41 & $135 * * *$ & $-72,8$ & $34 * * *$ & .76 & 32 & 8 \\
\hline US 20 / 20Alt E & -42.5 & 110 & $-1,679$ & 3 & .16 & 44 & 13 \\
\hline US 20 / Alt W & 2.77 & $-36 * *$ & $1,803 * * *$ & 5* & .27 & 36 & 9 \\
\hline US 20 / OH 10 & 70.5*** & $-73.3 * * *$ & $3,302 * * *$ & $44 * * *$ & .68 & 61 & 18 \\
\hline US 20 Alt $\mathrm{M}$ & $13.7 * *$ & $-33.1 * * *$ & $1,873 * * *$ & $8 * * *$ & .22 & 76 & 19 \\
\hline US $20 \mathrm{M} 1$ & $208 * * *$ & -57.8 & $3,999 * * *$ & 78*** & .74 & 79 & 22 \\
\hline US $20 \mathrm{M} 2$ & 54 & -173 & $8,486 *$ & 1 & .13 & 33 & 11 \\
\hline US $20 \mathrm{~W} 1$ & -39.2 & 587 & $-7,841$ & 0.2 & .05 & 15 & 5 \\
\hline US $20 \mathrm{~W} 2$ & $80.3 * * *$ & $-46.1 * * *$ & $2,259 * * *$ & $74 * * *$ & .70 & 88 & 22 \\
\hline US $20 \mathrm{~W} 3$ & $73.7 * * *$ & $-93.1 * * *$ & $3,695^{* * *}$ & $32 * * *$ & .86 & 16 & 4 \\
\hline US 224 & 6.02* & 2.41 & $640 * * *$ & 6** & .08 & 188 & 49 \\
\hline US $224 \mathrm{E}$ & $78.2^{*}$ & -59.5 & 2,662* & $26 * * *$ & .81 & 20 & 6 \\
\hline US $224 \mathrm{~W}$ & $22.5 * * *$ & $-28 * *$ & $1,598 * * *$ & $7 * *$ & .22 & 72 & 18 \\
\hline US 24 & 1.00 & $188 * * *$ & -534 & $24 * * *$ & .52 & 60 & 15 \\
\hline US $250 \mathrm{~N}$ & $93.9 * * *$ & -25.5 & $2,173 * * *$ & 89*** & .92 & 23 & 6 \\
\hline US $250 \mathrm{~S}$ & 22.8 & 6.93 & 1,079 & $42 * * *$ & .63 & 75 & 25 \\
\hline US $30 \mathrm{E}$ & -1.26 & 94.1 & 1,018 & $42 * * *$ & .36 & 210 & 59 \\
\hline US $30 \mathrm{M}$ & $115 * * *$ & -8.07 & $3,128 * * *$ & $43 * * *$ & .43 & 161 & 45 \\
\hline US $30 \mathrm{~W}$ & $66.8^{* *}$ & 32.2 & $3,189 * * *$ & $11 * * *$ & .35 & 61 & 18 \\
\hline US 33 & 46.2*** & 66.1*** & 953* & 60*** & .41 & 235 & 61 \\
\hline US $422 \mathrm{E}$ & $97.4 * * *$ & 61.6*** & -478 & $107^{* * *}$ & .91 & 32 & 9 \\
\hline US $422 \mathrm{~W}$ & 239 & -105 & 3,976 & $32 * * *$ & .80 & 27 & 9 \\
\hline US $6 \mathrm{E}$ & 61.6* & -45.3 & 1,989* & $14 * * *$ & .49 & 37 & 11 \\
\hline US 6 W1 & $30.2^{* *}$ & -8.77 & $1,616^{* * *}$ & $5 *$ & .16 & 76 & 23 \\
\hline US 6 W2 & $57.5 * * *$ & 51.6* & $1,436 *$ & $13 * * *$ & .25 & 108 & 27 \\
\hline I 475 & $526 * * *$ & $-571 * * *$ & $19,045 * * *$ & $92 * * *$ & .88 & 36 & 10 \\
\hline I $70 \mathrm{E}$ & 11.5 & $501 * * *$ & $-1,064^{*}$ & $644 * * *$ & .88 & 234 & 61 \\
\hline $\mathrm{I} 70 \mathrm{M}$ & $84.7 * *$ & $968 * * *$ & $-9,678 * * *$ & $584 * *$ & .94 & 99 & 27 \\
\hline I $70 \mathrm{~W}$ & $714^{* * * *}$ & -88.8 & $11,350 * * *$ & $512 * * *$ & .96 & 63 & 21 \\
\hline $\mathrm{I} 71 \mathrm{M}$ & 118 & $456 * * *$ & -237 & $204^{* * * *}$ & .91 & 59 & 18 \\
\hline I $71 \mathrm{~N}$ & 231 & -238 & $8,555^{*}$ & $7 * *$ & .39 & 33 & 9 \\
\hline I $71 \mathrm{~S}$ & $140 * *$ & $501 * * *$ & -374 & $149 * * *$ & .84 & 77 & 20 \\
\hline I $75 \mathrm{M}$ & $-68.5 * *$ & $1,174 * * *$ & $-16,152^{* * *}$ & $1,161^{* * *}$ & .95 & 180 & 53 \\
\hline I 75 N1 & -27.6 & $1,142 * * *$ & $-14,169 * * *$ & $565 * * *$ & .96 & 65 & 20 \\
\hline I 75 N2 & 60.5 & $909 * * *$ & $-11,505^{* * *}$ & $486 * * *$ & .95 & 76 & 19 \\
\hline I $76 \mathrm{E}$ & $205 * * *$ & 2.77 & $8,853 * * *$ & $25 * * *$ & .62 & 44 & 11 \\
\hline I $76 \mathrm{~W}$ & $485^{* * *}$ & $-374^{* *}$ & $12,669 * * *$ & $124 * * *$ & .93 & 28 & 7 \\
\hline I 77 & 58 & 110 & 3,051 & $120 * * *$ & .83 & 68 & 17 \\
\hline
\end{tabular}

\section{Results: The Extent of Diversion to Other Ohio Highways}

Table 9 shows the results of these regressions. Most of the roads/routes used in the model showed significant gains in traffic that appear to be related to the estimated Turnpike diversions. All coefficients except three had the expected sign. Using the coefficients, we can calculate diversions in average trucks per day given the estimated toll-road diversions in 2004. We show these estimated increases in daily truck counts 
and 95\% confidence intervals in Table 10 below. The highest estimated increases are on US 20 from US 250 to $\mathrm{OH}$ 420, for OH 2 between I 90 and US 6, and for US 442 between $\mathrm{OH} 82$ and $\mathrm{OH} 44$. All of these roads roughly parallel the Turnpike. Several other roads appear to have significant increases in traffic from Turnpike diversions. In total, the results appear to be close to those found by Ohio DOT in comparing traffic volumes before toll increases and after Turnpike truck tolls reductions to pre-1996 levels (ODOT \& ODPS, 2006). Two-lane roads are in bold type. Most notable of these are OH-2 from US-6 to I-280 (1,665 estimated additional trucks per day in 2004) and OH-18 between I-71 and I-77 (1,457 estimated additional trucks per day). Reported construction may have affected estimations for I-475 and US-30. Likewise, a tremendous jump in traffic on I-70 west of I-75 probably is more likely linked to events other than Turnpike diversions.

Table 10

2004 Predicted Diverted Daily Trucks

(Two Lane Highways in Bold)

\begin{tabular}{|c|c|c|c|c|c|}
\hline & & & & $95 \%$ Con & e Interval \\
\hline $\begin{array}{c}\text { Road } \\
\text { Segment }\end{array}$ & $\begin{array}{l}\text { Beginning of } \\
\text { Segment }\end{array}$ & $\begin{array}{l}\text { End of } \\
\text { Segment }\end{array}$ & Expected & Low & High \\
\hline I $70 \mathrm{~W}$ & I 75 & IN & 9,510 & 7,525 & 11,494 \\
\hline I 475 & All & & 7,006 & 4,888 & 9,123 \\
\hline I $76 \mathrm{~W}$ & Akron & I 71 & 6,460 & 4,608 & 8,311 \\
\hline $\mathrm{OH} 2 \mathrm{E}$ & I 90 & US 6 & 3,663 & 1,998 & 5,328 \\
\hline US $20 \mathrm{M} 1$ & $\mathrm{OH} 412$ & US 250 & 2,770 & 2,224 & 3,330 \\
\hline I $76 \mathrm{E}$ & I 80 & Akron & 2,715 & 1,377 & 4,053 \\
\hline I $71 \mathrm{~S}$ & US 30 & Columbus & 1,865 & 662 & 3,050 \\
\hline OH 2 M & US 6 & I 280 & 1,665 & 452 & 2,877 \\
\hline US $30 \mathrm{M}$ & $\begin{array}{c}\text { I } 75 \text { (excluding } \\
\text { Columbus) }\end{array}$ & I 71 & 1,552 & 1,030 & 2,024 \\
\hline OH 18 E & I 71 & I 77 & 1,452 & 350 & 2,571 \\
\hline US $442 \mathrm{E}$ & $\mathrm{OH} 44$ & OH 82 & 1,297 & 1,055 & 1,545 \\
\hline US $250 \mathrm{~N}$ & US 20 & US 224 & 1,251 & 996 & 1,505 \\
\hline I $70 \mathrm{M}$ & Columbus & I 75 & 1,127 & 378 & 1,878 \\
\hline US 20 W2 & OH 49 & US 20 ALT & 1,070 & 890 & 1,249 \\
\hline US $224 \mathrm{E}$ & US 250 & I 71 & 1,043 & 51 & 2,038 \\
\hline US 20 W3 & OH 49 & IN & 982 & 637 & 1,327 \\
\hline US 20 / OH 10 & OH 18 & Turnpike & 939 & 719 & 1,159 \\
\hline OH $18 \mathrm{~W}$ & US 20 & I 71 & 912 & 671 & 1,153 \\
\hline US $30 \mathrm{~W}$ & IN & I 75 & 890 & 312 & 1,465 \\
\hline US $6 \mathrm{E}$ & US 20 & OH 2 & 820 & 174 & 1,465 \\
\hline US 6 W2 & IN & US 24 & 766 & 390 & 1,141 \\
\hline US 33 & Columbus & IN & 615 & 338 & 892 \\
\hline US 6 W1 & US 24 & OH 53 & 402 & 108 & 697 \\
\hline US $224 \mathrm{~W}$ & OH 18 & US 250 & 300 & 132 & 466 \\
\hline US 20 Alt M & OH 108 & OH 2 & 182 & 52 & 314 \\
\hline US 224 & SR 18 & IN & 80 & 6 & 154 \\
\hline I $75 \mathrm{M}$ & US 30 & I 70 & $\begin{array}{l}-912 \\
\end{array}$ & $-1,505$ & $-3,157$ \\
\hline
\end{tabular}




\section{Discussion}

Based on these results, one can estimate what might happen if Ohio were to privatize the Turnpike. First, we estimate the average toll for trucks in 2004 at $\$ 0.46$ per mile in nominal dollars. ${ }^{13}$ Second, this increased toll could result in diversions from the Turnpike more than four times as great as those previously experienced in Ohio. ${ }^{14}$ Although calculating the safety effect of this diversion is beyond the scope of this paper, we know enough about the frequency and severity of crashes based on highway type to suggest that a substantial increase in crashes, crash severity, and fatalities in the State of Ohio probably would occur as a result of this diversion. In 2002, 23\% of all fatal crashes in the United States occurred on divided highways four lanes or wider, with the remainder on a mix of highways comparable to those to which traffic was diverted (Campbell, 2005). Third, the State of Ohio and various local governments would be unable to maintain local roads without significant increases in taxes or revenue generation of some sort, forcing the state either to toll all reasonable alternative highways, restrict through trucks from these highways, or increase fuel taxes for those buying fuel anywhere in the state (a cross-subsidy that would be inefficient and unpopular politically). Fourth, there would be a deadweight loss to the economy resulting from firms (of all types) using higher cost alternatives and consequently producing less.

While this analysis is limited to Ohio and the major alternative routes to I-80 through Ohio, we can generalize some lessons to other states. Although the evidence supporting the above prediction is compelling, the effects of toll increases for other highways would be different, depending on different substitute roads, different costs of diversion, and therefore a different elasticity of demand for that particular set of highways. However, the same general rules should apply. If the elasticity of demand is lower, then prices probably would rise higher before significant diversions would occur, but significant diversions would still occur. Because we know that secondary roads pose greater safety hazards, the safety cost of diversion will be substantial. Some deadweight loss and negative externalities to the economy necessarily will occur, as well, because truckers will divert to less efficient highways in spite of the cost in time, fuel, wear-andtear on the equipment, and added crash risk that insurance policies generally cannot capture. If the elasticity of demand is higher, then diversions will occur at a lower toll rate, but would still occur.

While the results from both the study of Turnpike traffic and the study of local Ohio traffic are strong, the analysis would have been stronger if other independent variables such as road construction and targeted enforcement against truck traffic could

13 This assumes that a private operator would have no contractual limit on rates. Most lease agreements limit how fast rates can rise, but not how high they can go.

${ }^{14}$ The accuracy of the numbers is questionable because no data exist for tolls over $\$ 0.30$ per VMT. However, while the absolute increase in diverted traffic may be different, this analysis shows that it will increase substantially. 
have been included. ${ }^{15}$ Likewise, annual counts of traffic rather than triennial counts would greatly improve the accuracy of the model. One way around this would be to create a diversion model based on cost (time, distance, and tolls) that predicts traffic for all routes simultaneously. Another useful addition for future research would directly measure the safety effects of diversions.

\section{Conclusion: Why is this Important?}

Hopefully the results of this study will add clarity to the debate on PPPs. The debate over PPPs is confused because little distinction is made between private operation, and private control on one hand and congestion pricing and private tolling on the other. One issue is whether policy makers decide to charge tolls rather than rely on taxes. The question of who sets the rate and who benefits is another issue. The foregoing analysis suggests that if private operators (or public operators for that matter) set toll rates to maximize profit where congestion is not a significant problem, they can introduce substantial inefficiencies in the overall road transportation network and actually increase congestion and safety hazards in other parts of the system that they do not own and control. These inefficiencies, the cost of which are borne by the public and not by the private toll road owner who is focused on profit for his particular part of the network, can only exist when private operators control particular strategically located roads through a purchase or long-term lease. This does not preclude having PPPs where private firms build, maintain, and operate roads but do not retain control. Missing from much of the discussion about road privatization is the effect of contracting out management functions without loss of public control of the road.

It is curious that national policy clearly supports sales (or long-term leases) of roads to private parties when such negative results can reasonably be expected. It does not appear that the USDOT has considered how far tolling and highway privatization should go. It also does not appear that the USDOT has considered how such a marketbased system of interstate highways will affect the parallel system of publicly-owned state and local roads or has considered the effect of private tolling on interstate commerce - unless the USDOT is already committed to toll-based financing for all roads. It is important that the effect of shifting from fuel taxes to tolls as well as highway privatization be understood better before the United States implements changes that will be very costly to reverse. If the estimated benefits do not substantially outweigh the costs before policy implementation, the cost of reverting to fuel taxes as well as to public ownership and control will be prohibitive if the system fails.

The fact that states and state politicians support PPPs is easier to understand. First, states do not print their own money and often have constitutional requirements to balance their budgets. States can structure lease deals to maximize their up-front money to resolve this year's budget crisis, but the cost will be passed on to future users as well as to interstate commerce in the form of inefficient freight traffic. This is especially true for states in which a substantial portion of users are passing through - especially when

${ }^{15}$ In early 2004, Ohio stepped up enforcement against trucks on selected two-lane roads in an effort to force diverted traffic back onto the Turnpike (ODOT and ODPS 2006). 
the users are engaged in interstate commerce and have no suitable substitute roads. These states are in position to collect rents on the sale or lease of a monopoly asset in a strategic location and outsiders must pay most of the bill. There is ample evidence that maximizing immediate cash flow is a primary priority for the lease deals that have been consummated so far. First, the size of the lump-sum payment to the state depends on the expected cash flows. Public infrastructure owners can increase expected cash flows by allowing non-compete clauses in the lease contract, by allowing faster and/or larger toll increases, and by increasing the length of the lease. We can see evidence of all three in existing lease contracts. Texas appears to be poised to allow fairly restrictive noncompete clauses in its master contract with Cintra (Hartzel \& Hoppe, 2007) and Indiana's limited non-compete clause may cause Indiana trouble in the future (George, Raphael, Trommer, \& McDermott, 2006). California had to buy back its lease of the express lanes of SR-91 because of restrictive non-compete clauses that it accepted in the lease contract (Sullivan, 2003) in order to make other necessary capacity expansions to the Los Angeles freeway system. Indiana raised toll rates for the Indiana Toll Road by over $70 \%$ before the lease was consummated (Enright, 2006), arguably artificially raising the value of their asset sale. The net present value of this increase alone was worth almost one quarter of the \$3.85 billion concession fee for the Toll Road (Enright, 2006). Tolls will increase another $78 \%$ over the next three years and can increase by at least $2 \%$ per year beyond that. ${ }^{16}$ While the elasticity of demand will provide an eventual cap on rates, it is not clear how high rates actually will go or how much traffic will divert to other roads as lessors maximize their profits. Worse for the nation is the fact that many highways like the Indiana Toll Road and the Chicago Skyway have a large proportion of traffic from other states. To the extent that leased roads carry mostly out-of-state traffic, it is advantageous to the leasing state to maximize the selling price with little regard to the eventual toll rates. The tendency for this to happen has been demonstrated by Levinson (2002) as the "Beggar Thy Neighbor" principle.

These rents that states are collecting in lump-sum payments are bad for the economy for two reasons in addition to the cost of traffic diversion. First, use of the resource (the highway) will decline due to the higher price, and users will substitute another resource (another road or supply chain path) that will not be as good as the road they avoided at a price based on marginal or average cost. Consequently, the user will lose utility by having to substitute a second-best alternative. This economic cost, or "deadweight loss," represents an economic loss for society. In terms of freight, artificially raising the cost of using interstate highways compared with using noninterstate highways would impair interstate commerce and thereby cause a deadweight loss to the economy. Second, rent-seekers (in this case, private road operators) will undertake activity to continue or to increase their ability to collect rents. Such activities can take the form of political lobbying and/or court actions. Macquarie's purchase of dozens of local newspapers in Texas (Anon, 2007), arguably to affect public opinion in the area targeted for their private highway, shows the ability of an infrastructure investor with deep pockets to influence public opinion; the operator of SR-91 sued California governments to enforce rigorously it's interpretation of a non-compete clause in the lease

16 The actual possible annual increase is the maximum of two percent, the CPI increase, and the GDP increase over the preceding year(s). 
agreement (Sullivan, 2003). Efforts by private operators to retard expansion of other road infrastructure clearly are not in the public interest. While rent by itself is merely a transfer of wealth and therefore not wealth destroying, non-value-adding efforts to maintain rents are considered wealth destroying.

Finally, the problem that policy makers seek to fix - the lack of available public economic resources to pay for highway maintenance and expansion - has always been solvable in the United States because governments can finance public investment using tax-free municipal bonds. In other words, access to private capital should not be a barrier to public investment as long as public bodies are willing to finance such investments using public funds to pay off the debt. If the true problem is that political leaders are unwilling to face the voters with the reality that there is no free lunch, then the problem we seek to solve by tolling and privatization will not solve the problem at all. In fact, our research suggests that it will only make the problem worse.

\section{References}

Allen, W. B. (2005). Alternative Methods for Estimating State Welfare Gains from Economic Deregulation of Intrastate Motor Freight Carriage: A Comparison of Results. Transportation Journal, 44(1), 45-61.

Anon. (2007, January 24, 2007). Macquarie Media Group buys US newspaper business for $\$ 102 \mathrm{~m}$. Australian Associated Press.

BLS. (2007). Producer Price Index-Commodities Series WPU14 Transportation Equipment (Publication. Retrieved March 30, 2007, from Bureau of Labor Statistics: http://data.bls.gov/cgi-bin/surveymost

Bryan, J., Blair, J., Lu, L., Atherton, S., Rathore, R., \& Johnson, E. (2004). The Impact of Tolls on Freight Movement for I-81 in Virginia: Reebie Associates, Atherton, Mease \& Company,Viginia Department of Rail and Publit Transit, Virginia Department of Transportation.

Button, K. J. (2006). How Should the Revenues from Congestion Pricing Be Spent? In G. Roth (Ed.), Street Smart: Competition, Entrepreneurship, and the Future of Roads (pp. 225-242). London: Transaction Publishers.

Campbell, K. L. (2005). Estimates of the Prevalence and Risk of Fatigue in Fatal Crashes Involving Medium/Heavy Trucks Update for 1991-2002 TIFA Files (Letter Report to FMCSA): Federal Motor Carrier Safety Administration.

Canada Newswire. (2005a, August 16, 2005). Arbitrators Rule in Favour of 407 ETR: 2002 is Base Year. Canada NewsWire.

Canada Newswire. (2005b, September 15, 2005). Province Appeals Arbitration Decision on Base Year Dispute with 407 ETR. Canada NewsWire. 
CBO. (1997). Toll Roads: A Review of Recent Experience. from http://www.cbo.gov/ftpdocs/40xx/doc4014/1997doc03-Entire.pdf

Enright, D. J. (2006). Then There Were Two: Indiana vs. Chicago Skyway. Jersey City, NJ: NW Financial, Group, LLC.

Fair, M. L., \& Williams, E. W. (1975). Economics of Transportation and Logistics. Dallas, TX: Business Publications, Inc.

FHWA. (1974-2007). Highway Statistics Publications. from http://fhwainter.fhwa.dot.gov/policy/ohpi/hss/hsspubs.htm

George, C., Raphael, R., Trommer, S., \& McDermott, M. (2006). U.S. Toll Road Privatizations: Seeking the Balance: FitchRatings.

Gronau, R. (1999). The Economics of a Single Toll Road in a Toll-Free Environment. Journal of Transport Economics and Policy, 33(2), 163-172.

Hartzel, T., \& Hoppe, C. (2007, March 8, 2007). Effort to Limit Toll Roads Gains Steam. The Dallas Morning News.

Klein, D., \& Majewski, J. (2006). America's Toll Road Heritage: The Achievements of Private Initiative in the Nineteenth Century. In G. Roth (Ed.), Street Smart: Competition, Entrepreneurship, and the Future of Roads (pp. 277-303). London: Transaction Publishers.

Lee, D. B., Jr. (2002). Induced Demand and Elasticity: US DOT/Volpe Center.

Levinson. (2002). Financing Transportation Networks. Northampton, MA: E. Elgar Publishing.

Mitchell, D. J. B. (2006). Earl Warren's Fight for California's Freeways: Setting a Path for the Nation. Southern California Quarterly, 88(2), 205-238.

ODOT, \& ODPS. (2006). Impact of the Northern Ohio Freight Strategy on Traffic and Safety Across the Northern Ohio Road Network: Ohio Department of Transportation and Ohio Department of Public Safety.

Ohio, G. o. (2004). Taft Plan to Improve Safety and Mobility in Northern Ohio. Columbus, $\mathrm{OH}$ : Governor's Office.

Ohio Turnpike Commission. (1983). Comprehensive Annual Financial Report for the year ended December 31, 1982. Berea, OH: Ohio Turnpike Commission.

Ohio Turnpike Commission. (1992). Comprehensive Annual Financial Report for the year ended December 31, 1991. Berea, OH: Ohio Turnpike Commission. 
Ohio Turnpike Commission. (2006). Comprehensive Annual Financial Report for the year ended December 31, 2005. Berea, OH: Ohio Turnpike Commission.

Pindyck, R. S., \& Rubinfeld, D. L. (1998). Microeconomics (Fourth ed.). Upper Saddle River, NJ: Prentice Hall.

Poole, R. W. (2005). A Response to Critics of Toll Road Leasing. Public Works Financing, 205, 2-3.

Proctor, G., \& Morckel, K. L. (2004). Northern Ohio Freight Strategy: Recommendations to Improve Traffic Safety and Congestion: Ohio DOT and Ohio DPS.

Schmidt, J. (2005). Counterpoint. Public Works Financing, 205, 9-10.

Shrank, D., \& Lomax, T. (2005). The 2005 Urban Mobility Report from http://tti.tamu.edu/documents/mobility_report_2005_wappx.pdf

Small, K. A., Winston, C., \& Evans, C. A. (1989). Road Work: A New Highway Pricing and Investment Policy. Washington, DC: The Brookings Institution.

Sullivan, E. C. (2003, November 19-22, 2003). Impact Study of Value Pricing on California State Route 91. Paper presented at the International Symposium on Road Pricing, Key Biscayne, FL.

TRB. (2006). The Fuel Tax and Alternatives for Transportation Financing (Special Report No. SR 285). Washington, DC: TRB Committee for Study of the LongTerm Viability of Fuel Taxes for Transportation Finance.

USDOT. (2004). Report to Congress on Public-Private Partnerships. Washington, DC: United States Department of Transportation.

USDOT. (2006, May 2006). National Strategy to Reduce Congestion on America’s Transportation Network. from http://isddc.dot.gov/OLPFiles/OST/012988.pdf 